\title{
IUELTAL
}

\section{Collocations in the English LKS Books for Senior High School Students}

\author{
Odilia Listya Alfiandita \\ Sanata Dharma University \\ e-mail:odiliaalfiandita@gmail.com \\ Priyatno Ardi \\ Sanata Dharma University \\ e-mail:priyatnoardi@usd.ac.id
}

\begin{abstract}
:
This article investigates the types and variations of collocations used in English Lembar Kerja Siswa (LKS) books for senior high school students. The researchers employed corpus analysis in conducting this study. Data were collected from five English LKS books for grade $X, X I$, and XII Senior High School (SMA/SMK/MA). AntConc 3.5.8 was used to extract the data, which were then analyzed to find out the types and variations of collocations in the books. The findings revealed that the books consisted of Grammatical G1 (1804 tokens), Grammatical G2 (1 token), Grammatical $G_{3}$ (423 tokens), Grammatical $G_{4}$ (4664 tokens), Grammatical $G_{5}$ (1 token), Grammatical G7 (34 tokens), Lexical L1 (3889 tokens), Lexical L3 (533 tokens), Lexical L4 (687 tokens), Lexical L5 (4 tokens), and Lexical L7 (2 tokens) collocations. Grammatical $G_{4}$ collocation was mostly found in the LKS books. Furthermore, the collocation types in the English LKS books by grade levels were not various. The researchers suggest that English teachers should introduce collocations in their teaching to help the students to acquire the natural use of English.
\end{abstract}

Keywords: collocation, English LKS books, senior high school 


\section{Introduction}

Collocation, a group of words that frequently occurs together (Woolard, 2000; Yule, 2017), plays an important role in the process of English language learning. EFL students in Indonesia need to learn collocations since the combinations of words cannot be replaced by other words so that the students need to know which combination of words is appropriate. As a result, the students can improve their vocabulary items and re-activate the half-known words in the form of word combinations (Lewis, 2000; Woolard, 2000). Possessing a high competence in collocation, the students can produce the natural use of English. Nesselhauf and Tschichold (2002) state that the students having a lack of collocation knowledge tend to make some grammatical mistakes because they do not know the appropriate word combinations to express their thoughts. Producing incorrect collocations will eventually lead to a misunderstanding between the addressers and the addressees (Henriksen, 2013).

As English textbooks can be one of the sources of learning English collocations, some scholars have investigated the use of collocations in textbooks. Koya (2004a) compared the revised English textbooks with the former English textbooks in Japan. He found that all of the books paid a little attention to collocations. There was only a small number of the collocation variation in the books. Koya (2004b) also compared the UK history books with the English I textbooks for 1oth-grade students in Japan. He found that the UK history books had fewer collocations than the Japanese English textbooks due to the fact that the UK history books focused only on history itself rather than the grammatical matters. Moreover, Wang and Good (2007) conducted a study to find out the repetitive use of collocations in three EFL textbooks from southern Taiwan. They found that the variation of collocations was limited. Roohani (2011)also conducted a study to compare high school and pre-university English textbooks from the Ministry of Education with the New Interchange book series in Iran. The results revealed that the New Interchange book series had a larger number of collocations than the English textbooks for high school and pre-university students.

The present study aims to analyze the collocations in Lembar Kerja Siswa (LKS) books used by senior high school students in Indonesia. The students are usually provided with two kinds of textbooks, namely Buku Paket and Lembar Kerja Siswa (LKS) books. The former is long, while the latter is shorter, containing exercises with a short explanation about the materials. The English $L K S$ books are published to enrich the students' English skills through independent learning either in the class or at home (Damayanti et al., 2013). Based on the background, two research questions are formulated as follows:

1. What types of collocations are commonly found in the English LKS books for senior high school students?

2. How do the collocations in the English LKS books for senior high school students vary by grade levels?

\section{Literature Review}

The researchers adopt the theoretical framework by Benson et al. (2010) and Lewis (2000) who categorize collocations into grammatical and lexical collocation. The former contains a lexical word or dominant word (noun, verb, or adjective) with grammatical structure (infinitive or clause), which includes noun + preposition combination, noun followed by to + 
infinitive, noun followed by that clause, preposition + noun combination, adjective + preposition combination, predicate adjectives followed by to infinitive, and adjective followed by that clause. The latter is the combination of two lexical components that normally do not contain any preposition, infinitives or clause, which includes verb (transitive) + noun/pronoun, verb + noun, adjective + noun, noun + verb, the unit that is associated with a noun, adverb + adjective, and verb + adverb.

Even though Benson et al. (2010) and Lewis (2000) share similar perspectives on types of collocations, they have different classifications. Regarding the combination of verb + noun, Lewis (2000) considers this pattern as one type, while Benson et al. (2010) classify the pattern into two types. The first type is the verb + noun collocation with the verb denoting creation and/or activation, called CA collocation. The second type is the verb + noun collocation with the verb meaning eradication and/or nullification, called as EN collocation. As regards noun + noun collocation (Benson et al., 2010; Lewis, 2000) categorize noun + noun collocation into two types, namely Lexical $L 3$ collocation (adjective + noun) and Lexical $L_{5}$ collocation (the unit that is associated with a noun). Benson et al. (2010) state that nouns are also often used as adjectives (e.g. house arrest and jet engine). Lexical L5 collocation consists of the unit associated with noun (e.g. colony of bees).

\section{Methodology}

This research is corpus-based research. Corpus linguistics is the study of language from the real-life language or the daily life language used in the society (Hasko, 2013; McEnery \& Wilson, 2001). It is the written text or the huge collection of more than one written texts from the daily life language in the form of computer files (Baker, 2010; Kennedy, 1998; McEnery \& Wilson, 2001). The researchers analyzed the pattern of collocations in the books. Moreover, the variation of collocation based on each grade was investigated. In doing so, the researchers used AntConc 3.5.8 to extract the data and find out the tokens and types of words (Anthony, 2004, 2005).

\subsection{Data Source}

The researchers examined the collocations in five English $L K S$ books for grade $\mathrm{X}, \mathrm{XI}$, and XII Senior High School (SMA/SMK/MA). The English LKS books were published in Yogyakarta and Klaten, Indonesia. The details of the books are in Table 1.

Table 1 List of the English $L K S$ books

\begin{tabular}{llll}
\hline No. & Title & Author(s) & Publisher \\
\hline 1. & Pakar: Bahasa Inggris XA Wajib & Riska Nurdiana, S.S. & CV Aviva (2017) \\
\hline 2. & $\begin{array}{l}\text { Belajar Praktis Bahasa dan } \\
\text { Sastra Inggris: Kelas X Semester } \\
\text { 2 }\end{array}$ & $\begin{array}{l}\text { Bening Sarwini, Candra Kirana, } \\
\text { Catur Setyaning R, et al. }\end{array}$ & Viva Pakarindo (2017) \\
\hline 3. & $\begin{array}{l}\text { Belajar Praktis Bahasa Inggris } \\
\text { Untuk SMA/MA Kelas XI } \\
\end{array}$ & Adi Nur Cahyo, Anjas Prastowo, & Viva Pakarindo (2017) \\
& Atikah Anindyarini, et al. & \\
\hline 4. & $\begin{array}{l}\text { PR Bahasa Inggris } \\
\text { SMA/MA/SMK?MAK Kelas XI }\end{array}$ & $\begin{array}{l}\text { Bachtiar Bima M, Cicik Kurniawati, } \\
\text { et al. }\end{array}$ & Intan Pariwara (2017) \\
\hline 5. & Pemester 2 & & \\
& SMA/MA/SMK/MAK Kelas XII & Bachtiar Bima M, Cicik Kurniawati, & Intan Pariwara, 2018 \\
\end{tabular}




\subsection{Instruments and Data Collection}

To obtain the data, the researchers took two steps. First, the printed LKS books was scanned into PDF files. Second, the PDF files were converted into Word files using an online PDF converter, namely www. freepdfconvert.com. AntConc 3.5.8 (Anthony, 2005) was used to extract the data. The steps of extracting the data included opening the AntConc 3.5.8 software, clicking "File", clicking "open file(s)", choosing the files from the computer, and clicking the "word list" and "start" at the bottom of the page.

\subsection{Data Analysis}

The data analysis included four steps. First, the researchers read the collected data to deepen the understanding of the gathered data. The collected data were the words and letters in the English LKS books. However, not all words and letters could be analyzed to find the collocation types and variation. Therefore, in this step, the researchers decided which words could be included in the collocation analysis based on the fourteen types by Lewis (2000) and Benson et al. (2010). The words were noun, preposition, adjective, verb, and adverb. Second, the researchers took the first ten mostly used words from the list. Since the majority of those words were function words, the researchers took the next ten content words.

Next, the researchers analyzed the twenty words based on the types of collocation. There are fourteen types of collocation divided into two categories, namely lexical and grammatical collocation. To categorize the words into collocation types, the researchers used fourteen codes as the symbol of the collocation types namely $G_{1}, G_{2}, G_{3}, G_{4}$, $G_{5}, G 6$, and $G_{7}$ for grammatical collocation and $L_{1}, L_{2}, L_{3}, L_{4}, L_{5}, L_{6}$, and $L_{7}$ for lexical collocation. In grammatical collocation, G1 was noun + preposition combination, G2 was noun followed by to + infinitive, $G_{3}$ was noun followed by that clause, $G_{4}$ was preposition + noun combination, $G_{5}$ was adjective + preposition combination, $G 6$ was predicate adjectives followed by to + infinitive, and $G_{7}$ was adjective followed by that clause. In lexical collocation, L1 was verb + noun (CA collocation), L2 was verb + noun (EN collocation), L3 was adjective + noun, $\mathrm{L}_{4}$ was noun + verb, $\mathrm{L}_{5}$ was the unit that is associated with a noun, $\mathrm{L} 6$ was adverb + adjective, and L7 was verb + adverb.

Lastly, the researchers compared the words from each grade level to find out the variation of words mostly used in English LKS books for senior high school students. The researchers compared the first twenty words from English LKS books for grade X, XI, and XII Senior High School (SMA/SMK/MA). After that, the researchers figured out what kind of words mostly used in each grade and how those words varied by grade levels to further investigate the possible collocation types formed by the mostly found words among the grade levels.

\section{Results and Discussion}

\subsection{Types of Collocation in the English LKS Books for Senior High Schools Students}

The researchers extracted the data from the English LKS books to get the words and their total number by using the Antconc toolkit. The researchers took the top ten words found in the English LKS books for senior high school students, as presented in Table 2. 
Table 2 Ten Words Mostly Found in English LKS Books

\begin{tabular}{|l|l|l|}
\hline No. & Word & Frequency \\
\hline 1. & Is & 2912 \\
\hline 2. & In & 2846 \\
\hline 3. & Are & 1387 \\
\hline 4. & What & 1367 \\
\hline 5. & That & 1208 \\
\hline 6. & On & 1022 \\
\hline 7. & Be & 1004 \\
\hline 8. & Can & 972 \\
\hline 9. & Have & 964 \\
\hline 10. & Will & 924 \\
\hline
\end{tabular}

The findings showed that the ten words were mostly function words. Function words are more likely to fulfil the grammatical matters, which consist of auxiliary verb, preposition, article, conjunction, and pronoun (Corver \& Riemsdijk, 2001). In Table 2, the word "is" and "are" were the auxiliary verb. In these LKS books, the word "in" and "on" were the prepositions. The word "what" and "that" here were the pronouns. The next one was the word "can" and "will" which could be identified as a noun and an auxiliary verb. In this research, both words "can" and "will" were used as the auxiliary verb. Furthermore, the word "have" was presented as a verb and an auxiliary verb. The word "be" was used as a verb. It means that among the first ten mostly used words found in English LKS books for senior high schools students, only the word "be" and "have" were possible to be the content word.

Since there are a lot of function words in the top ten words, the researchers decided to do further analysis for the next words to find ten content words. The content word consists of noun, verb, adjectives, and adverb (Corver \& Riemsdijk, 2001). The content words mostly found in the English LKS books are in Table 3.

Table 3 Ten Content Words Mostly Found in English LKS Books

\begin{tabular}{|l|l|l|}
\hline No. & Word & Frequency \\
\hline 1. & Text & 724 \\
\hline 2. & Do & 701 \\
\hline 3. & Following & 560 \\
\hline 4. & How & 507 \\
\hline 5. & Questions & 474 \\
\hline 6. & Like & 436 \\
\hline 7. & Task & 419 \\
\hline 8. & People & 408 \\
\hline 9. & Answer & 387 \\
\hline 10. & When & 387 \\
\hline
\end{tabular}


It could be seen in Table 2 and Table 3 that the gap between the function words and the content words was small. As a part of content words, the majority of those words were nouns and verbs. The word "text", "answer", and "questions" could be identified as a noun or verb. The word "do", "like" and "following" could be categorized as verbs. However, the word "following" could also be included as an adjective (e.g. the following text), which means coming next. The words "task" and "people" were nouns. Meanwhile, the word "how" was categorized as an adverb (Hornby et al., 1974).

The researchers then combined the results of the function words and content words. To do so, the researchers listed the twenty words mostly found in the English $L K S$ books for senior high school students as presented in Figure 3.

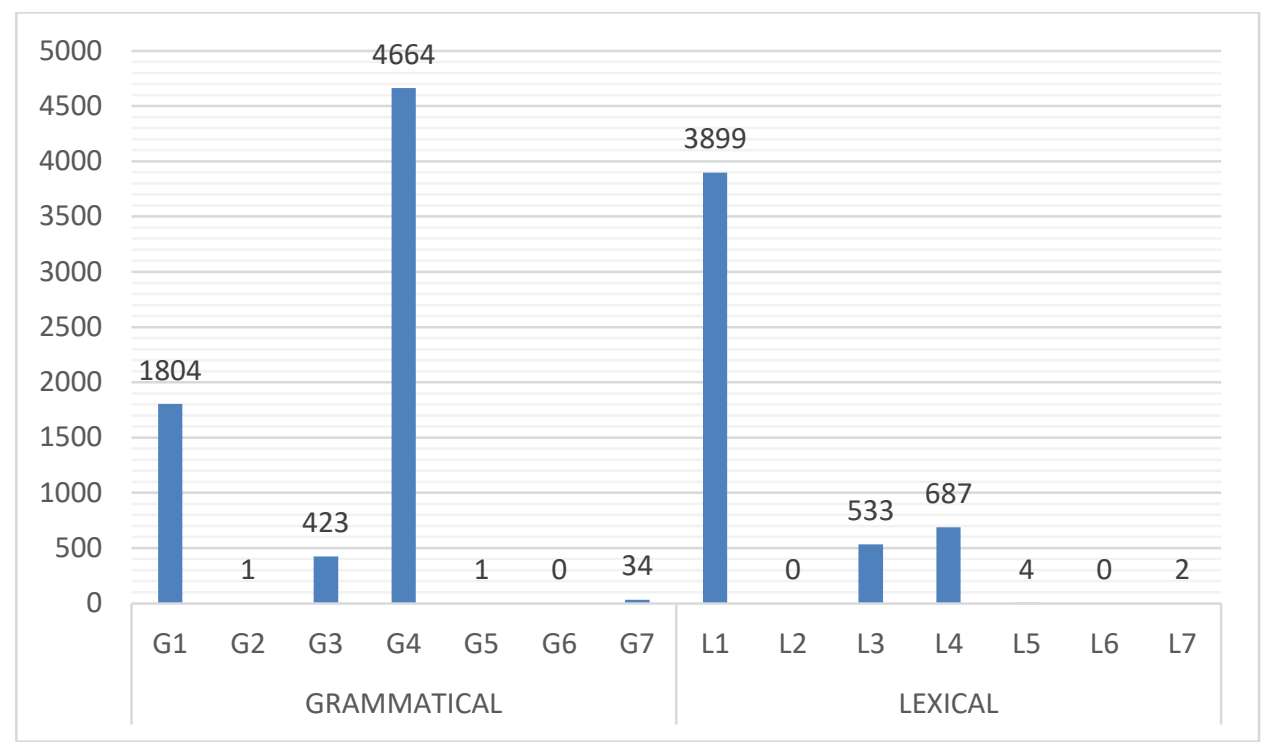

Figure 3. Collocation Types Mostly Found in English LKS Books

Figure 3 shows two big categories of collocations. The first one was the grammatical collocation which had seven types of collocation, namely Grammatical $G_{1}, G_{2}, G_{3}, G_{4}, G_{5}$, G6, and G7 collocation. The second one was the lexical collocation which also has seven types of collocation, namely Lexical L1, L2, L3, L4, L5, L6, and L7 collocation.

The findings showed that among fourteen collocation types, there were eleven types found in the English $L K S$ books for senior high school students. In this research, Grammatical $\mathrm{G}_{4}$ collocation, whose pattern is preposition + noun combination, was the highest among all (Benson et al., 2010). Lexical L1 collocation, with the pattern verb + noun, was found to be the second after Grammatical $G_{4}$ collocation. Meanwhile, the researchers did not find any of Grammatical G6, Lexical L2, and Lexical L6 collocation in the data.

\subsubsection{Grammatical G1 Collocation}

Based on Figure 3, Grammatical $\mathrm{G}_{1}$ collocation was in the third position with the frequencies of 1804 . This kind of collocation consists of noun + preposition combination (e.g. documents in a big envelope) (Benson et al., 2010). Since Grammatical G1 collocation includes prepositions, the mostly found Grammatical $G_{1}$ collocation was formed by the word "in" with the total number of 1094. The examples of Grammatical G1 collocation are as follows. 
(1) Saute the onion in 2 tablespoons of butter...

(2) Cook the burgers in a little oil for 3-4 minute per side.

It could be seen in sentences (1) and (2) that the noun + preposition pattern occurred in "the onion in" and "the burgers in."

Furthermore, the preposition "on" was included in Grammatical G1 collocation. The word "on" was in the second position after the word "in" to form Grammatical G1 collocation with the total number of 377 . Therefore, since a preposition is included in Grammatical $\mathrm{G}_{1}$ collocation, the prepositions, such as "in" and "on" were dominant in this collocation type.

There were six words that played a role as the noun in the G1 collocation, namely "text", "questions", "like", "task", "people", and "answer". The example is as follows.

(3) The text below is for questions number 1 to 5.

Sentence (3) shows the Grammatical G1 collocation in the English LKS books. The word "text" was the noun which was followed by the word "below" as the preposition. There were 148 words "text" found in these English LKS books.

\subsubsection{Grammatical G2 Collocation}

Based on Figure 3, Grammatical G2 collocation was in the twelfth position with the total frequency of one. There was only one word "do" formed the Grammatical G2 collocation in these English $L K S$ books.

\section{(4) What is Intan's suggestion to do now?}

Sentence (4) was taken from one of the questions in the English LKS books. The word "suggestion" was a noun while "to do" was infinitive. This was the only Grammatical G2 collocation found in this research. This happened because Grammatical $\mathrm{G}_{2}$ collocation has some rules. In Grammatical G2 collocation, to + infinitive here should be only associated with the noun rather than the whole sentence. In another word, it could not show the purpose or could not be added "in order to" before to + infinitive, e.g. they sold their house (in order) to cut down the expenses. Moreover, in Grammatical G2 collocation, nouns could not follow the descriptive adjective (e.g. an interesting book to read (Benson et al., 2010).

\subsubsection{Grammatical $\mathrm{G}_{3}$ Collocation}

Grammatical $G_{3}$ collocation was on the sixth place among all of the collocation types. As seen in Figure 3, Grammatical $G_{3}$ collocation was under Lexical L3 collocation and above Lexical L7 collocation. The total number of this type was 423. The words "that" and "text" were included in Grammatical $G_{3}$ collocation. There were 417 words (34.52\%) in this type. The examples are as follows.

(5) The chief mandarin stood to make an announcement that Calaf's answer was correct.

(6) I heard through the breeze that business is going well there.

In sentences (5) and (6), it can be seen that "an announcement" was noun and "that Calaf's answer was correct" was that clause. It proved that this was the Grammatical G3 collocation whose pattern was noun followed by that clause. It was also proven by the use of that clause 
rather than that using a relative clause (e.g. an announcement that was correct) (Benson et al., 2010). Grammatical $G_{3}$ collocation could also be seen in the use of the word "text".

(7) We know from the text that the participant of the seminar must ...

(8) It can be implied from the text that bouquet of love is Nugroho's

Sentences (7) and (8) contained the noun followed by that clause pattern. The word "text" here stood as a noun and the words "that the participant of the seminar must ..." are that clause. There were only six words of word "text" which were categorized as Grammatical $\mathrm{G}_{3}$ collocation.

\subsubsection{Grammatical $\mathrm{G}_{4}$ Collocation}

Grammatical $\mathrm{G}_{4}$ collocation consists of preposition + noun combination (Benson et al., 2010). Since this type of collocation does not have any specific rules, this type was the mostly used type in this research. It can be seen in Figure 3 that this type was in the first place which had the highest frequency among the others. The number of frequency of this type was 4663, above the Lexical L1 collocation. The word "in" mostly appeared as the member of Grammatical $\mathrm{G}_{4}$ collocation. There were 2830 Grammatical $\mathrm{G}_{4}$ collocation patterns formed by the word "in".

(9) To help the woman look for items in a mall.

(10) We plan to go fishing in a lake near my uncle's house.

Sentences (9) and (10) contained Grammatical G4 collocation. In sentence (9), the word "in" was the preposition followed by "a mall" as a noun. Meanwhile, in sentence (10), the word "in" was the preposition while "lake near my uncle's house" was the noun combination.

The words "on", "about", "text", "following", "questions", "like", "task", "people", "answer", and "when" were also mentioned in the form of Grammatical $G_{4}$ collocation. The last one was the word "when" that was only found once in this study. The following sentence is the example.

(11) Conjunction should be used to make connections like when, and, but.

In sentence (11), the authors of the book explained the use of conjunctions by adding the words "when", "and" and "but" as the examples. The word "like" here played a role as the preposition, while the word "when", "and" and "but" here were the nouns (Hornby et al., 1974). Therefore, the word "when" was identified as a noun. From the pattern, it could be proven that this sentence contains the Grammatical $\mathrm{G}_{4}$ collocation pattern, with the word "like" as the preposition and the word "when" as the noun.

\subsubsection{Grammatical $G_{5}$ Collocation}

The pattern of Grammatical $G_{5}$ collocation is adjective + preposition combination (Benson et al., 2010; Lewis, 2000). This preposition combination occurs in the predicate. There was only one collocation regarded as Grammatical $G_{5}$ collocation. Based on Figure 3, Grammatical $\mathrm{G} 5$ collocation was in the twelfth position.

(12) For example, your skin is white like snow. 
Sentence (12) was the only Grammatical $G_{5}$ collocation found in this research. The word "white" was the adjective followed by the word "like" as a preposition. The adjective has to be the predicate adjective which follows the linking verbs.

\subsubsection{Grammatical G7 Collocation}

Grammatical G7 collocation consists of adjective followed by that clause (Benson et al., 2010). There were 34 Grammatical $G_{7}$ collocations found. The number of Grammatical $G_{7}$ collocation was lower than that of Lexical L6 collocation and higher than that of Grammatical $G_{5}$ collocation and Lexical $L_{5}$ collocation. The words "that" and "text" were found to be the part of Grammatical $\mathrm{G}_{7}$ collocation. There were 33 Grammatical $\mathrm{G}_{7}$ collocation formed by the word "that". It means that $2.73 \%$ the word "that" formed the Grammatical G7 collocation. The following is the example of the Grammatical $G_{7}$ collocation formed by the word "that".

(13) (Its, It's) true that homing pigeon will find (its, it's) ...

(14) It is obvious that it is the author who will be doing ...

Sentences (13) and (14) proved that Grammatical G7 collocation was found in the English LKS books for senior high school students. The word "true" here was the adjective which was followed by "that homing pigeon will find (its, it's) ..." as a clause. Since there were 33 Grammatical G7 collocations formed by the word "that", there was only one Grammatical G7 collocation formed by the word "text". The following is the example of the Grammatical G7 collocation formed by the word "text".

(15) To make sure that the text has changed.

Sentence (15) was taken from the multiple-choice question in the English $L K S$ books for senior high school students. It showed the existence of the Grammatical G7 collocation. The word "sure" was the adjective and "that the text has changed" was that clause.

\subsubsection{Lexical L1 Collocation}

Lexical L1 collocation consists of verb + noun/pronoun (Benson et al., 2010; Lewis, 2000) In this Lexical L1 collocation, the verb expresses creation and/or activation (Benson et al., 2010). Based on Figure 3, there were 3.899 Lexical L1 collocations in the English LKS books for senior high school students. In this research, this collocation type had the highest frequency among the lexical collocations. However, Lexical I collocation was in the second position among all the types of collocations. Furthermore, from the top twenty words, there were eight words which were not included in Lexical L1 collocation, namely the word "is", "in", "are", "on", "can", "will", "how" and "when". Besides, the word "following" was counted as the most-found word formed Lexical L1 collocation.

(16) lin and Alin are following a competition as the representative from ...

In sentence (16), the word "following" was identified as a verb and "a competition" as a noun. Meanwhile, the least was found in the word "task". The examples are as follows.

(17) You still have enough time to finish the task.

(18) ... wanted to be the first to complete any task. 
Even though the researchers found that the word "task" occurred 419 times, there were only two words "task" used in Lexical L1 collocation. It means that only a few of the word "task" was used in the English LKS books for senior highs school students. In further analysis, the word "task" was mostly used as the title of the exercise in the English LKS books (e.g. TASK 1, TASK 2, etc.). However, sentences (17) and (18) showed the existence of the word "task" as the part of Lexical L1 collocation. The word "finish" was a verb and "the task" had a role as the noun.

\subsubsection{Lexical L3 Collocation}

Lexical L3 collocation consists of adjective and noun (Benson et al., 2010; Lewis, 2000). Based on the findings, this type of collocation was not popular in the English LKS books. There were 533 Lexical L3 collocation found. The number was lower than that of Lexical L4 collocation and higher than that of Grammatical $G_{3}$ collocation. Among the top twenty mostly found words, the words "text", "questions", "task", "people", and "answer" were found in the formation of Lexical L3 collocation. The word "text" was mostly used in the Lexical L3 collocation.

(19) This incomplete text is for number 13 to 15.

(20) Read the following text!

Sentences (19) and (20) were taken from the instructions in the English LKS books. The word "incomplete" was the adjective and the word "text" was a noun. Sentences (19) and (20) were the proofs of the existence of Lexical $L_{3}$ collocation since they followed the pattern adjective + noun. From all the words "text" found, $28.45 \%$ formed the Lexical L3 collocation.

While the word "text" was mostly found as part of Lexical L3 collocation, the word "task" occurred five times (1.19\%). The following is the Lexical $L_{3}$ collocation formed by the word "task".

(21) You will read the words in the next task.

(22) Police's women corps will have the additional task of monitoring students spending time at shopping.

Sentences (21) and (22) contain the Lexical L3 collocation pattern, namely adjective + noun. The word "next" was an adjective followed by the word "task" as a noun. Furthermore, the word "additional" was also identified as an adjective while the word "task" was as a noun.

\subsubsection{Lexical L4 Collocation}

Lexical L4 collocation consists of noun + verb (Benson et al., 2010; Lewis, 2000). In this paper, Lexical $L_{4}$ collocation was found to be the fourth among the other collocation types. There were 670 Lexical L4 collocation formations. The words included "have", "text", "do", "following", "questions", "like", "task", "people", and "answer". From the nine words, the word "people" was mostly found word in Lexical L4 collocation formation, playing a role as a noun in the noun-verb collocation.

(23) Minangkau people adopt the culture

(24) Some people believe that the facilities of the park is ... 
In sentences (23) and (24), the word "people" was a noun followed by "adopt" and "believe" as verbs that designate the action characteristic of the noun (Benson, Benson, \& Ilson, 2010).

\subsubsection{Lexical L5 Collocation}

Lexical $L_{5}$ collocation contains the unit that is associated with a noun (Benson et al., 2010). In this paper, the use of Lexical $L_{5}$ collocation became the ninth. There were only four formations of Lexical $L_{5}$ collocation found, which were formed by the word "people". The examples are as follows.

(25) Millions of people-particularly from South-east Asia-either lack these enzymes or carry faulty versions, said the team.

(26) There are a large number of people in Hotel Armico.

Sentences (25) and (26) show the pattern of Lexical L5 collocation. "Millions of people" was included in the unit that is associated with a noun. Moreover, this type of collocation often consists of noun ${ }_{1}$ and noun ${ }_{2}$. The example shows "millions" as the noun ${ }_{1}$ and "people" as the noun $_{2}$.

\subsubsection{Lexical L7 Collocation}

Lexical L7 collocation is the verb and adverb combination (Benson et al., 2010; Lewis, 2000). In this research, there were two Lexical L7 collocations. It made the Lexical L7 collocation became the tenth among the other types of collocation. From the twenty words, there were two words that were in the formation of Lexical L7 collocation, namely "do" and "have".

(27) They can do freely with it, for example pornography sites.

(28) The photocopiers can produce copies that have virtually the same size as the original item.

In sentence (27), the word "do" was the verb which was followed by the word "freely" as an adverb. From the sentence (28), the word "have" played as the verb while the word "virtually" was the adverb. Both sentences (27) and (28) proved the existence of Lexical L7 collocation.

\subsection{Variation of Collocations in the English LKS Books for Senior High School Students by Grade Levels}

After extracting the total words in the English $L K S$ books, the researchers identified the total used words from each grade. There were 52.304 word tokens from grade $X, 55.673$ word tokens from grade $\mathrm{XI}$, and 73.872 word tokens from grade XII. The researchers took twenty mostly used words in the English LKS books. The top twenty words were taken based on BBI Combinatory Dictionary of English (Benson et al., 2010). The following figure shows the top 20 used words from grade $X$. 


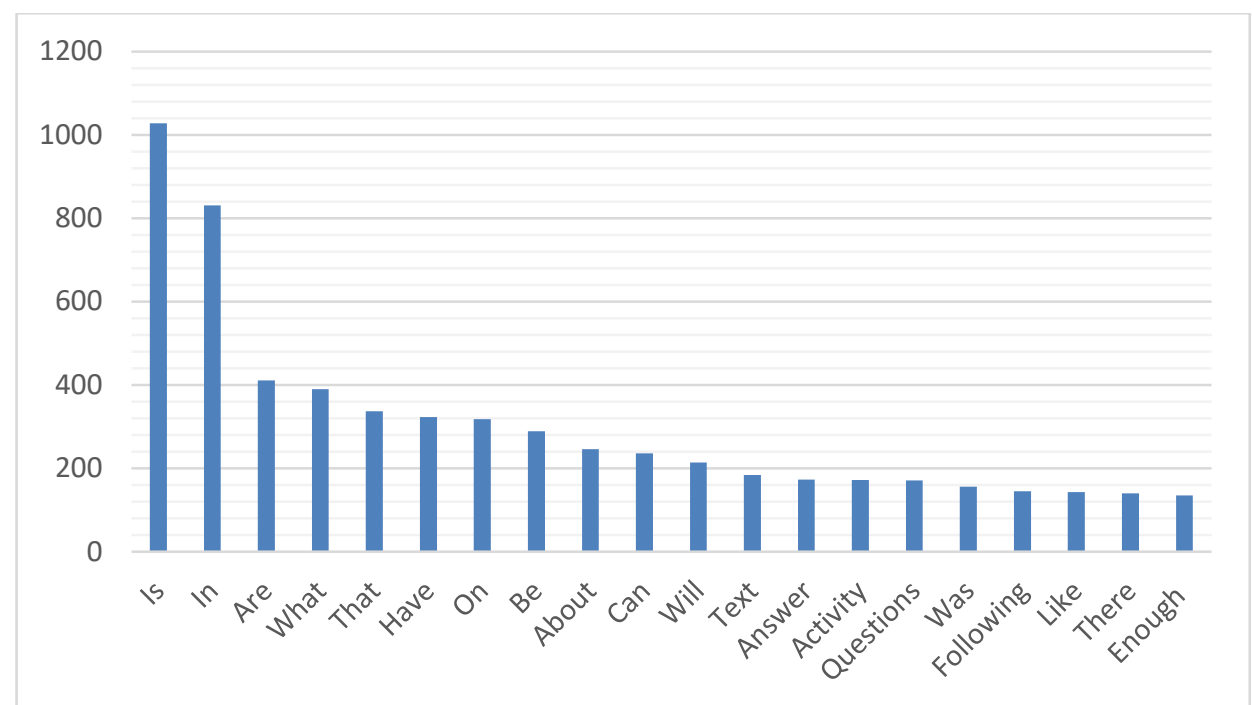

Figure 4 Twenty Words in the English LKS Books for Grade X Senior High School (SMA/SMK/MA)

As seen in Figure 4, the word "is" was in the highest position among the others with the total number of 1.028. It was followed by the word "in" with the total number of 831. The word "enough", with the total number of 135 , became the last from the top twenty mostused words in the English LKS books for grade X. Furthermore, among the twenty words, the function words were in the top position. The word "is", "in", "are", "what", and "that" were the top five words. The researchers also found that the gap between the words "is" and "in" was not too far. However, the gap between the word "in" and the other words was quite big.

The word "is" could not be included in any collocation type because it was included as auxiliary verb (Benson et al., 2010; Lewis, 2000). However, the word "in" could form the collocation types which included prepositions, such as in Grammatical $\mathrm{G}_{1}$, Grammatical G4, and Grammatical $G_{5}$ collocation. The word "are", as the third most-used word, also could not form any collocation types. Meanwhile, the fourth word "what" was found in Lexical L1 collocation. The researchers then found that the gap between the word "in" (831) and the word "what" (390) was quite big.

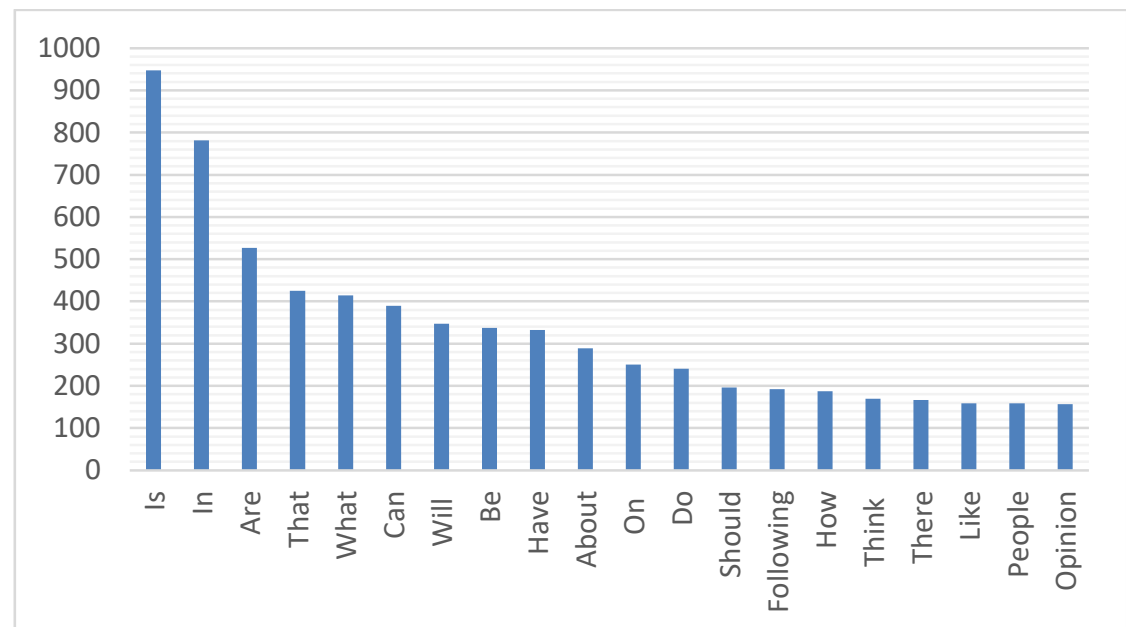

Figure 5 Twenty Words in the English LKS Books for Grade XI Senior High School (SMA/SMK/MA) 
Figure 5 presents the words mostly found in the English LKS books for grade XI. In the English LKS books for grade XI, the word "is" also led with the total number of 947. The second one was the word "in" with total number of 782. The last was the word "opinion" with the total number of 157 . Moreover, the first five words were also included as function words. The gap between words "is" and "in" was 165. Furthermore, the gap between the words "in" and "are" was 255, showing that the gap was bigger than that of the words "in" and "is".

The mostly found word in the books for grade XI was the word "is". The word "is" could not be included into any pattern of collocation types. Meanwhile, the word "in", as the second word, could form the collocation types that include preposition especially in the grammatical collocation. In the English LKS books for grade XI, the word "that' was found to be the fourth with the total number of 425 . The word "that" was mostly found in the form of Grammatical $\mathrm{G}_{3}$ collocation since this type consists of a noun followed by that clause (Benson et al., 2010).

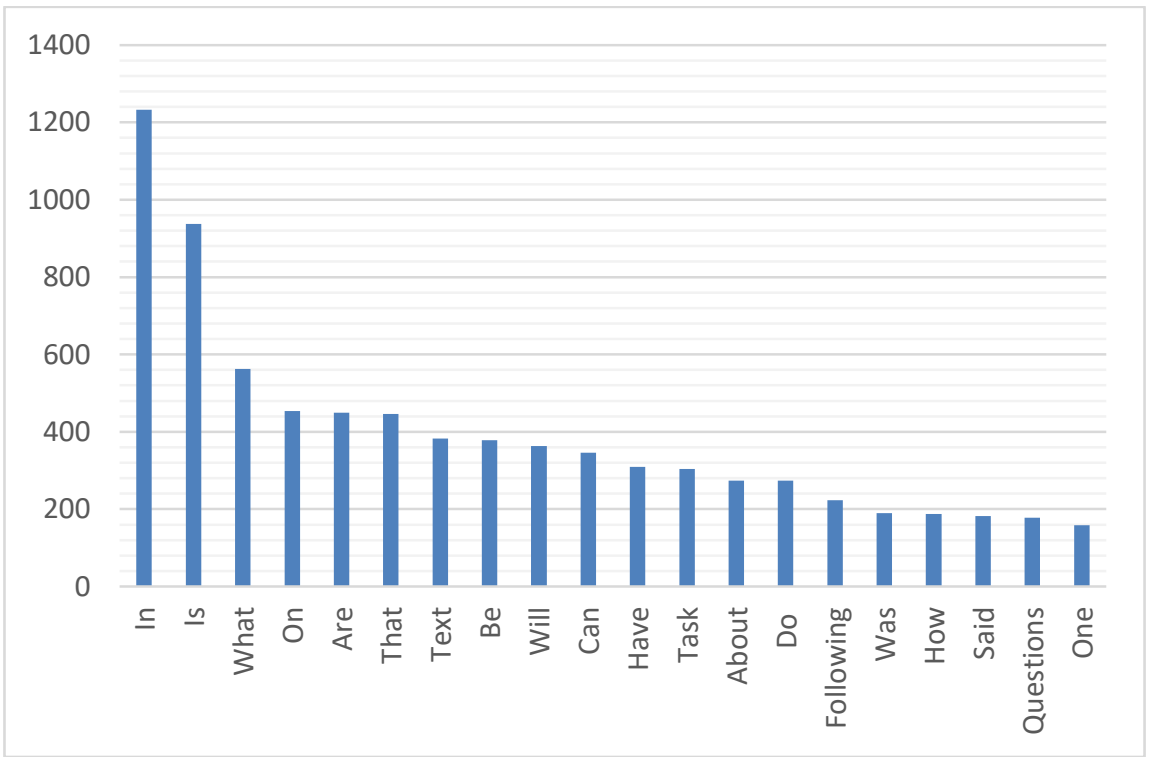

Figure 6 Twenty Words in the English LKS Books for Grade XII Senior High School (SMA/SMK/MA)

Figure 6 shows the top 20 words used in the English LKS books for grade XII. Different from the words from the English LKS books grade X and XI, in this book, the word "in" was found to be the mostly used word with the total number of 1233 . The word "is" was found to be the second with the total number of 937. Among those twenty words, the word "one" was the last with the total number of 158. Figure 6 also shows the gap between each word. In the English LKS books for grade XII, the gap is the same as those for grade X and XI. The first two words, "in" and "is", had a big gap while the other words did not have.

As the mostly found word in the English LKS books for grade XII, the word "in" could be included in the Grammatical $G_{1}$, Grammatical $G_{4}$, and Grammatical $G_{5}$ collocation. The second mostly found word, i.e. the word "is", could not form any type of collocation (Benson et al., 2010; Lewis, 2000). The word "what", as the third most-found word, was found to form the Lexical L1 collocation. 
The researchers found that the top eleven words used by the English $L K S$ books for grade $X$, $\mathrm{XI}$, and XII shared similarities. Figure 4, Figure 5, and Figure 6 show that the first eleven words from those grades were almost the same. The difference was only on the frequency of each word and the use word "text". Among the top eleven words, the word "text" only appeared in the English LKS books for grade XII. Thus, the variation in each grade was still far because there were a few differences from each grade.

The researchers also found some similarities in the use of the next nine words among the grade levels. The word "questions" used in grade X was also found in the result of grade XII. The word "like" used in grade X was also used in grade XI. Meanwhile, the word "following" was used in the three grades. However, there were some words which were only used in a certain grade. The words "text", "answer", "activity", and "enough" were only presented in the English LKS books for grade X. The words "should", "think", "people", and "opinion" were only used by grade XI. In addition, the words "task", "said", and "one" were only shown in grade XII.

\section{Conclusions}

The researchers draw two conclusions. First, the LKS books contained 14 types of collocation, which are categorized into two, namely grammatical collocation and lexical collocation. From the findings, between grammatical and lexical collocation, the grammatical collocation with the total number of 7819 . Meanwhile, the total number of lexical collocation was 5707. This happened because the mostly found words in the English $L K S$ books was a preposition used in the Grammatical $\mathrm{G}_{1}$ and $\mathrm{G}_{4}$ collocation. Second, the collocation variation was far from adequate. This was because the mostly found word in the English LKS books among grade levels was the word "in" as the preposition that can only form the Grammatical $G_{1}, G_{4}$, and $G_{5}$ collocation.

The findings showed that the collocation types were dominated by the grammatical collocations and the majority of the words were function words, which became the biggest support to the grammatical collocations. This showed that the English LKS books writers put less attention to the use of collocation types in the books. The researchers recommend the book writers vary the use of collocation types to help the students receive language inputs. The researchers would also suggest that English teachers explicitly teach English collocations with, according to Hill (2000), no more than 10 collocations per session. Exposures to collocations will help the students acquire the natural use of English.

\section{References}

Anthony, L. (2005). AntConc: Design And Development Of A Freeware Corpus Analysis Toolkit For The Technical Writing Classroom. International Professional Communication Conference Proceedings, 729-737.

Anthony, L. (2004). Antconc: A Learner And Classroom Friendly, Multi-Platform Corpus Analysis Toolkit. In L Anthony, S. Fujita, \& Y. Harada (Eds.), Proceedings Of Iwlel 2004 : An Interactive Workshop On Language E-Learning (p. 7-14). Iwlel.

Baker, P. (2010). Sociolinguistics And Corpus Linguistics. Edinburg University Press.

Benson, M., Benson, E., \& Ilson, R. (2010). The BBI Combinatory Dictionary Of English: Your Guide To Collocations And Grammar (3rd Ed.). John Benjamins Publishing Company. Corver, N., \& Riemsdijk, H. (2001). Semi-Lexical Categories. In N. Corver \& H. Riemsdijk 
(Eds.), Semi-Lexical Categories: The Function Of Content Words And The Content Of Function Words (Pp. 1-23). Mouton De Gruyter.

Damayanti, D. S., Ngazizah, N., \& K, E. S. (2013). Pengembangan Lembar Kerja Siswa ( LKS ) Dengan Pendekatan Inkuiri Terbimbing Untuk Mengoptimalkan Kemampuan Berpikir Kritis Peserta Didik Pada Materi Listrik Dinamis SMA Negeri 3 Purworejo Kelas X Tahun Pelajaran 2012 / 2013. Radiasi, 3(1), 58-62.

Hasko, V. (2013). Qualitative Corpus Analysis. In C. A. Chapelle (Ed.), The Encyclopedia Of Applied Linguistics (Pp. 1-6). Blackwell Publishing Ltd.

Henriksen, B. (2013). Research On L2 Learners' Collocational Competence And Development - A Progress Report. In C. Berdel, B. Laufer, \& C. Lindqvist (Eds.), L2 Vocabulary Acquisition, Knowledge And Use. New Perpectives On Assessment And Corpus Analysis. (Pp. 29-56). Eurosla.

Hill, J. (2000). Revising Priorities: From Grammatical Failure To Collocation Succes. In M. Lewis (Ed.), Teaching Collocation: Further Developments In The Lexical Approach (Pp. 47-69). Language Teaching Publication.

Hornby, A. S., Cowie, A. P., \& Lewis, J. W. (1974). Oxford Advanced Learner's Dictionary Of Current English. Oxford University Press.

Kennedy, G. (1998). An Introduction To Corpus Linguistics. Pearson Education Limited.

Koya, T. (2004a). A Comparison Of Verb-Noun Collocations Collected From Revised High School English Textbooks In Japan. The Bulletin Of The Graduate School Of Education Of Waseda University, 11(2), 55-70.

Koya, T. (2004b). Collocation Research Based On Corpora Collected From Secondary School Textbooks In Japan And In The UK. Dialogue, 3, 7-18.

Lewis, M. (2000). Language In The Lexical Approach. In M. Lewis (Ed.), Teaching Collocation: Further Developments In The Lexical Approach (Pp. 126-154). Language Teaching Publication.

Mcenery, T., \& Wilson, A. (2001). Corpus Linguistic: An Introduction (2nd Edition). Edinburg University Press.

Nesselhauf, N., \& Tschichold, C. (2002). Collocations In CALL: An Investigation Of Vocabulary-Building Software For EFL. Computer Assited Language Learning, 15(3), 251-279.

Roohani, A. (2011). Collocations In High School And Pre-University English Textbooks Versus New Interchange Book Series. The Journal Of Asia TEFL, 8(3), 55-81.

Wang, J. T., \& Good, R. L. (2007). The Repetition Of Collocations In EFL Textbooks: A Corpus Study. Proceedings Of The Sixteenth International Symposium And Book Fair On English Teaching, 223-232.

Woolard, G. (2000). Collocation - Encouraging Learner Indeoendence. In M. Lewis (Ed.), Teaching Collocation: Further Developments In The Lexical Approach (Pp. 28-46). Language Teaching Publication.

Yule, G. (2017). The Study Of Language (6th Edition). Cambridge University Press. 